\title{
Reproductive aspects of Harttia carvalhoi Miranda Ribeiro, 1939, a small loricariid from streams of serra da Mantiqueira eastern, SP, Brazil
}

\author{
Renan Hohendorff Biagiotto ${ }^{1,3}$, Giulianna Rondineli', \\ Alberto Luciano Carmassi ${ }^{I}$ \& Francisco Manoel de Souza Braga ${ }^{I}$ \\ ${ }^{1}$ Departamento de Zoologia, Instituto de Biociências, Universidade Estadual Paulista "Júlio de Mesquita \\ Filho”-UNESP, Av 24 A, 1515, Bela Vista, CP 199, CEP 13506-900, Rio Claro, SP, Brasil \\ ${ }^{2}$ Departamento de Produção Vegetal, Centro de Ciências Agrárias, Universidade Federal do Espírito \\ Santo - UFES, Alto Universitário, s/n, Guararema, CP 16, CEP 29500-000, Alegre, ES, Brasil \\ ${ }^{3}$ Corresponding author: Renan HohendorffBiagiotto, e-mail: hb.renan@hotmail.com
}

BIAGIOTTO, R.H., RONDINELI, G., CARMASSI, A.L. \& BRAGA, F.M.S. Reproductive aspects of Harttia carvalhoi Miranda Ribeiro, 1939, a small loricariid from streams of serra da Mantiqueira eastern, SP, Brazil. Biota Neotrop. 12(4): http://www.biotaneotropica.org.br/v12n4/en/abstract?shortcommunication+bn01512042012

Abstract: The aim of this work was to present the reproductive aspects of Harttia carvalhoi Miranda Ribeiro, 1939, a small loricariid whose distribution is restricted to the area of drainage basin of the Paraíba do Sul river. A total of 110 specimens of $H$. carvalhoi were captured. The reproductive period happens from September to February. A total spawning type was identified and fecundity rate ranged from 16 to 106 oocytes. This type of study is important, since fecundity is a specific feature and is adapted to the conditions of the life cycle, varying with growth, population density, food availability and mortality rate. We also emphasize the importance of this study, since there are no previous studies about the reproduction of this species.

Keywords: Loricariinae, sex ratio, reproductive period, fecundity, Brazil.

BIAGiOTto, R.H., RONDINELI, G., CARMASSI, A.L. \& BRAGA, F.M.S. Aspectos reprodutivos de Harttia carvalhoi Miranda Ribeiro, 1939, um pequeno loricariídeo de riachos do leste da serra da Mantiqueira, SP, Brasil. Biota Neotrop. 12(4): http://www.biotaneotropica.org.br/v12n4/pt/abstract?shortcommunication+bn01512042012

Resumo: O objetivo deste trabalho foi apresentar os aspectos reprodutivos de Harttia carvalhoi, Miranda Ribeiro, 1939, um pequeno loricariídeo cuja distribuição é restrita a área de drenagem do rio Paraíba do Sul. Um total de 110 exemplares de $H$. carvalhoi foi obtido. O período reprodutivo acontece desde Setembro até Fevereiro. O tipo de desova foi identificado como total e a taxa de fecundidade variou de 16 a 106 ovócitos. Este tipo de estudo é importante, visto que fecundidade é uma característica específica e é uma adaptação às condições do ciclo de vida, variando com o crescimento, densidade populacional, alimentos disponíveis e taxa de mortalidade. Nós também enfatizamos a importância deste estudo, pois não há estudos prévios sobre a reprodução desta espécie. Palavras-chave: Loricariinae, proporção de sexos, periodo reprodutivo, fecundidade, Brasil. 


\section{Introduction}

The serra da Mantiqueira system is a mountain range consisting of crystalline rocks located to the southeast of Brazil, being a watershed between the basins of the Grande river (MG) and the Paraíba do Sul river (SP). This in turn was formed, together with the Serra do Mar, by reactivation of a system of Precambrian rocks failures during the Oligocene-Miocene (Petri \& Fúlfaro 1983).

The eastern portion of the serra da Mantiqueira is steeper and scalloped, and from its slopes, numerous creeks descend form micro basins separated from each other by prominent ridges (Braga 2004). This is the context in which lies the watershed of the Piracuama river, a hydrographic network which descends the slope of this portion of the sierra and will disembogue in the left bank of the Paraíba do Sul river, being located in the municipality of Pindamonhangaba, São Paulo.

These drainage networks exhibit a rich fish fauna (Braga \& Andrade 2005, Rondineli 2010). However, very little is known about the biology of their species. For example we have the Loricariidae, which is a very diverse group of fish, but there are very few studies concerning its most representative family, the Loricariinae (Menezes et al. 1998). This family shows about 32 genera and 190 species, distributed among four tribes (Isbrücker 1980). Among these, we have the Harttia genus, which occurs and is abundant in the watershed of the River Piracuama. According to Menezes et al. (1998), there are five species concerning the Harttia genus, being four of them in Brazilian territory and one in Suriname.

The target species of this study is H. carvalhoi, a small loricariid (Figure 1), whose distribution is restricted to the area of drainage basin of the Paraíba do Sul river (Reis et al. 2003). Our aim in this work is the study of reproductive aspects, fecundity and spawning type of this species, which has never been addressed before.

Even though there are no such studies concerning the reproductive aspects of this species, there is previous study concerning the genus Harttia. Menezes et al. (1998) conducted a study with the species Harttia loricariformis Steindachner, 1876, whose distribution is also restricted to the Paraíba do Sul river basin. In this study the reproductive aspects were explored. His studies pointed to a multiple spawning strategy for the species, which contrasts with our results for $H$. carvalhoi. His results also pointed to a reproductive period that extends from September to February, which is in agreement with the species in the present study.

\section{Materials and Methods}

Samples were obtained in streams of Piracuama watershed during the months of April, July and October of 2009 and February of 2010. The collection points are located on the slope and piedmont: point $1-45^{\circ} 35^{\prime} 32^{\prime \prime} \mathrm{W}$ and $22^{\circ} 49^{\prime} 43^{\prime \prime} \mathrm{S}$, point $2-45^{\circ} 31^{\prime} 33^{\prime \prime} \mathrm{W}$ and $22^{\circ} 48^{\prime} 29^{\prime \prime} \mathrm{S}$, point $3-45^{\circ} 32^{\prime} 21^{\prime \prime} \mathrm{W}$ and $22^{\circ} 48^{\prime} 50^{\prime \prime} \mathrm{S}$ (Figure 2).

Fish was captured by electric fishing equipment with passages of $50 \mathrm{~m}$ for twice, without a contention net. All collected fish specimens were immediately preserved in $10 \%$ formalin, later transferred to $70 \%$ ethanol. Voucher specimens were deposited in icththyological collection of the Universidade Estadual Paulista, in Rio Claro, SP.

Standard length ( $\mathrm{Ls}, \mathrm{mm}$ ) and total weight (Wt, g) were taken from each specimen. Sex and gonadal maturity stages were identified considering texture, consistency, coloration, size and surface vascularization of gonads (Vazzoler 1996), through direct macroscopic observation. Four different gonadal mature states were considered: A, immature; B, in maturation or resting; C, mature; and $\mathrm{D}$, spent. For degree of fat accumulated in the visceral cavity were assigned following values: "1" for the visceral cavity that did not present fat, " 2 " for the visceral cavity partially filled with fat and " 3 " for the visceral cavity full of fat (Braga 1999).

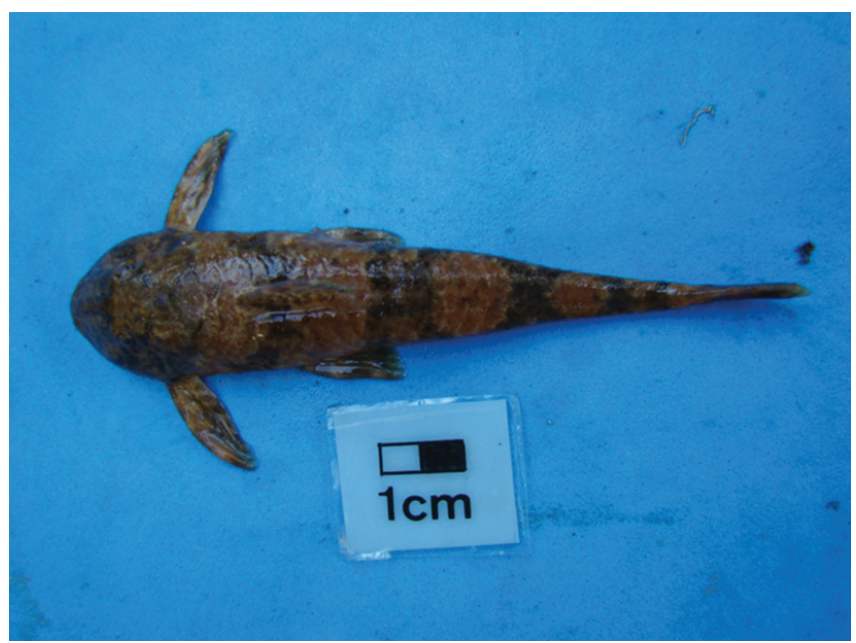

Figure 1. Harttia carvalhoi specimen captured on the streams of the Piracuama river micro basin.

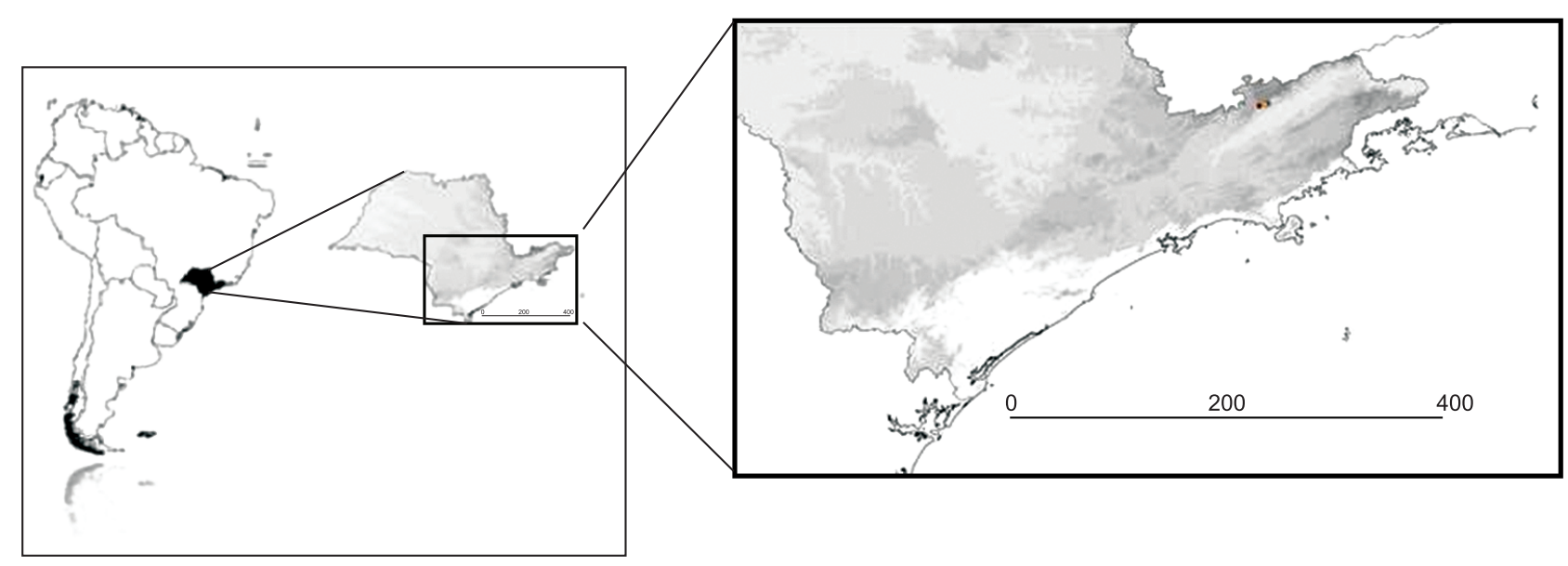

Figure 2. Map showing the three collection points: Point 1 (in red color), Point 2 (in green color) and Point 3 (in yellow color). 
To verify if the proportion between males and females of this species was different from the expected (1:1), the test of $\chi^{2}$ (Siegel 1975) was used, considering $\alpha=0.05$.

On account of the close relationship between the maturation progress of oocytes and the increase of volume, which implies an increase of the weight of the ovaries, the gonadossomatic relationship (RGS), that shows the percentage of gonads on individual's total weight, is an efficient indicator of the ovaries functional state (Vazzoler 1996). Also, temporary variation of RGS supplies information about the reproductive period of species or population. Therefore, inferences on the reproductive period of species were made through the frequency of individuals with gonads in different stages of maturity and the temporal variation in gonadossomatic relationship (RGS).

Female fecundity was estimated as the total number of vitelogenic oocytes produced during the reproductive period. Mature ovaries were removed, immersed in Gilson solution (Vazzoler 1996) for the complete detachment of ovarian membranes, washed and preserved in $70 \%$ alcohol. The type of spawning was determined by the frequency distribution of the oocyte diameter classes ( $1 \mathrm{D}$. O. $\mathrm{M}=61.2 \mu \mathrm{m}$ ) taken randomly from 100 oocytes of each female $(\mathrm{N}=14)$ (Vazzoler 1996).

\section{Results}

A total of 110 specimens of $H$. carvalhoi were captured. The population structure of the species concerning sex ratio was 40 females, 29 males and 41 immatures. The proportion between males and females did not differ from expected $\left(\chi^{2}=1.754 ; \mathrm{gl}=1\right.$; $\mathrm{p}=0.185$ ). The smaller specimen presented $22 \mathrm{~mm}$ of standard length (was an immature) and the largest was a male with $91 \mathrm{~mm}$ of standard length (Figure 3). Males and females did not show different standard length $\left(\mathrm{t}=0.68 ; \mathrm{gl}=1 ; \mathrm{p}=0.49 ; \mathrm{CP}_{\text {average }}\right.$ for males $=62.69 \mathrm{~mm}$; $\mathrm{CP}_{\text {average }}$ for females $=64.55 \mathrm{~mm}$ ). Relationship between standard length and total weight of males and females captured was presented by following equation $\mathrm{Wt}=0.00006 \mathrm{Ls}^{2.6587}(\mathrm{r}=0.98, \mathrm{n}=29)$ and $\mathrm{Wt}=0.00005 \mathrm{Ls}^{2.7148}(\mathrm{r}=0.98, \mathrm{n}=40)$, respectively.

Considering each sampling, the most expressive value of relative frequency of mature individuals occurred on sample 3 (Figure 4) and the gonadossomatic relationship presented growing values from sample 1 to sample 2, with subsequent slightly decreasing value in sample 3, following the tendency to sample 4 (Figure 5). Females with spent gonad (D) presented an amount of immature oocytes as well as some residual yolky oocytes. Those remaining yolky oocytes represent a parcel of oocytes that weren't expelled during reproduction, being reabsorbed by the female in time.

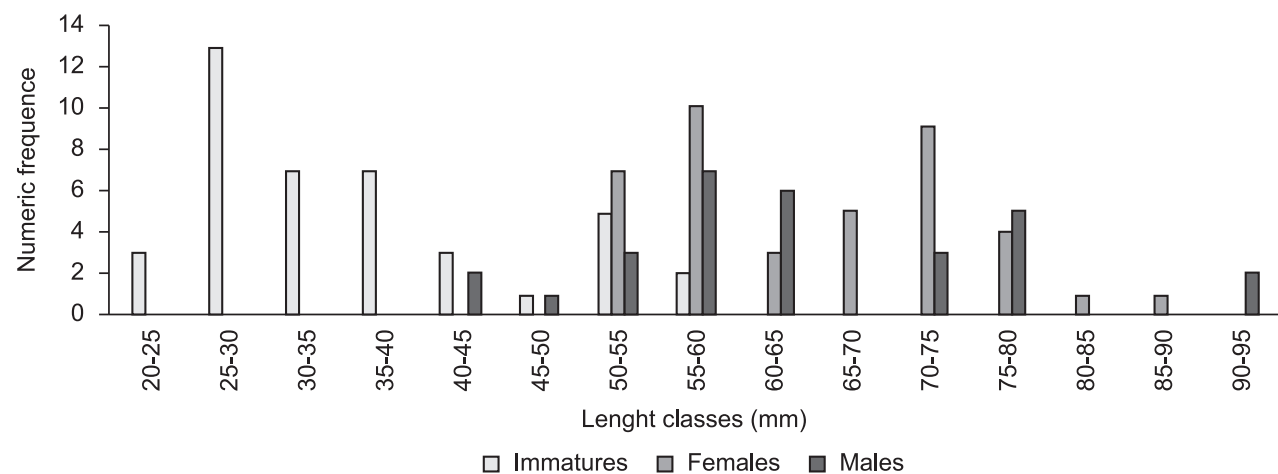

Figure 3. Numeric distribution of immature, females and males of Harttia carvalhoi according to class of standard length (mm).

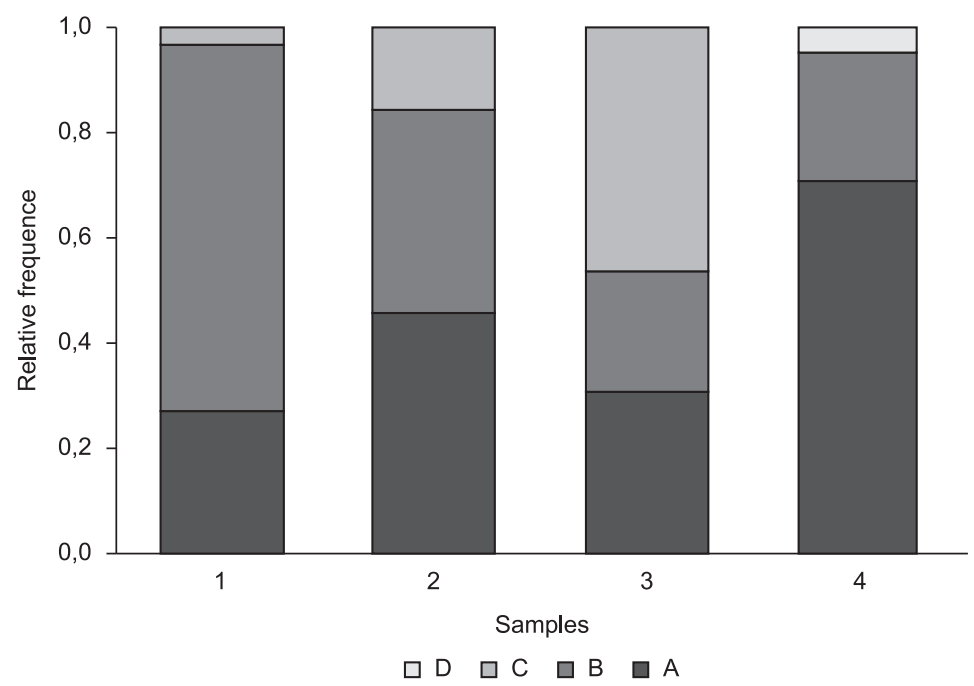

Figure 4. Relative frequency of Harttia carvalhoi individuals in different states of gonadal development in each samples (A, immature; B, in maturation or resting; $\mathrm{C}$, mature; and $\mathrm{D}$, spent). 


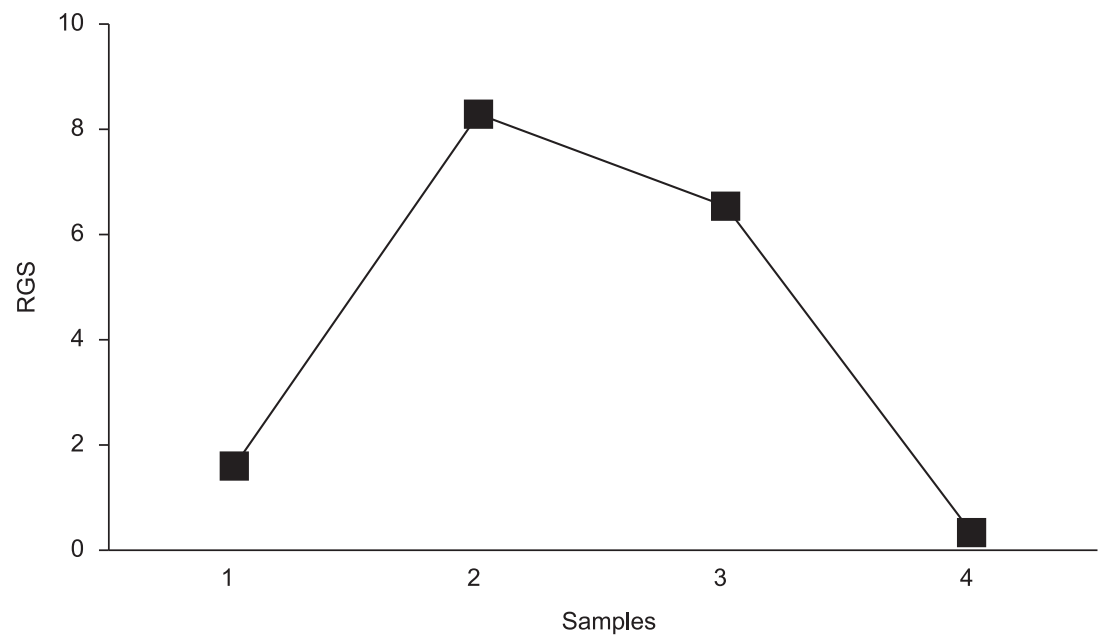

Figure 5. Gonadossomatic relationship (RGS) for mature females of Harttia carvalhoi in each samples.

When the distributions of diameter frequency of yolky oocytes were analysed, five groups were defined with two modes, being the first one corresponding to the immature oocytes, and the second one, which progresses in development among the groups, corresponding to the occytes in maturing process (Figure 6). The existence of two modes, being the greatest one corresponding to developing oocytes, suggests a total spawning type (synchronous in two groups).

The oocytes diameter varied from $61.2 \mu \mathrm{m}$ to $3,427.2 \mu \mathrm{m}$, being $1,652.4 \mu \mathrm{m}$ the measure from which we considered mature oocytes. The total number of oocytes ranged from 68 to 461 and the number of mature oocytes considered ( $\mathrm{N}=$ fecundity) ranged from 3 to 106. Group I shows an ovary that has not yet started the process of development; groups II and III, shows developing ovaries; group IV, mature ovaries and group V shows ovaries in the process of depletion. Considering group IV, with mature oocytes, the fecundity rate ranged from 16 to 106 oocytes.

\section{Discussion}

According to Nikolsky (1963), the variation in body size is a widespread occurrence of sexual dimorphism between fishes, with a predominance of females in larger size classes. Being the fecundity directly linked to the reproductive potential, and knowing the positive relationship between the size and fecundity of the female, a higher frequency of females distributed in classes of larger standard length is justified.

However, we also have significant frequency of males among the classes of higher default length, being the highest measures pertaining to them. This is also justified, because the male tends to be bigger in species which defend the offspring in the nest, assigning reproductive advantages for bigger male individuals (Shine 1990). The same justification serves to the work done by Menezes et al. (1998), with $H$. loricariformis species, whose highest measures and amplitude of standard length were attributed to males.

The proportion of males and females went as expected (1:1) for the total sample, similar to the finding made for the reproductive biology of $H$. loricariformis (Menezes et al. 1998). Still, despite the proportion 1:1 being common in fish studies, variations in prevalence of males and females in the various classes of length may be related to different seasons of study (Vazzoler 1996).

Analyzing the graph of the relative frequency of different states of gonadal maturation of $H$. carvalhoi per sample, it's possible to note a very subtle expression of mature gonads in the first sampling (in April). In the second sampling, in July, a growing number of mature gonads is evident, being a sign of closeness to the reproductive season. In the third sample, in October, the greatest proportion of mature gonads of all samples was found. The dominance of mature gonads in the third sample indicates that the species is already in the reproductive period. And finally, the fourth sample (in February) doesn't present mature gonads, but it does present immature gonads, maturing or resting gonads and the exclusive presence of depleted gonads, characterizing the end of the reproductive cycle, which indicates that the reproductive season happens from around September to February.

The relation of the RGS values also follows the same trend according to the reproductive cycle. An intense feeding during non-reproductive periods may represent a strategy for allocating energy for reproduction, when those energy reserves will be used in the oocytes maturating process (Nikolsky 1963), leading the RGS value to its lowest value (as seen in the $4^{\text {th }}$ sample). Thus, the low value of RGS for the first sample, followed by growing values in the second sample (close to the reproductive period) and the decline of RGS values during the reproductive period, indicates that there's a relation between the trends of both graphs. The decline is due to the spawning, which reduces the RGS values.

We can then relate the data to a reproductive period that probably stretches from September to February for H. carvalhoi. The data corresponds to a tendency seen in other representatives of the Loricariidae family, including different genus, such as Hypostomus luetkeni Lacèpéde, 1803, whose reproduction also corresponds to an extended spawning period, also lasting from September to February (Mazzoni \& Caramaschi 1997).

The evidences are not only found for different genus among the family Loricariidae, but also for the Harttia genus. Our result corresponds to another work done about the reproductive biology of the genus, with the species H. loricariformis (Menezes et al. 1998) which occurs in the same basin and presents a reproductive season that also goes from September to February. According to this same study, this species has shown reproductive activity in the same period as for most of the other species that occurs in the lower part of the Paraíba do Sul river basin, coinciding with higher temperatures and precipitation levels. This feature maybe connected to a seasonal reproductive strategy linked to favorable environmental factors.

An interesting point is that there are different spawning strategies reported for the Harttia genus, since $H$. loricariformis is reported to be a multiple spawning species (Menezes et al. 1998) and our 

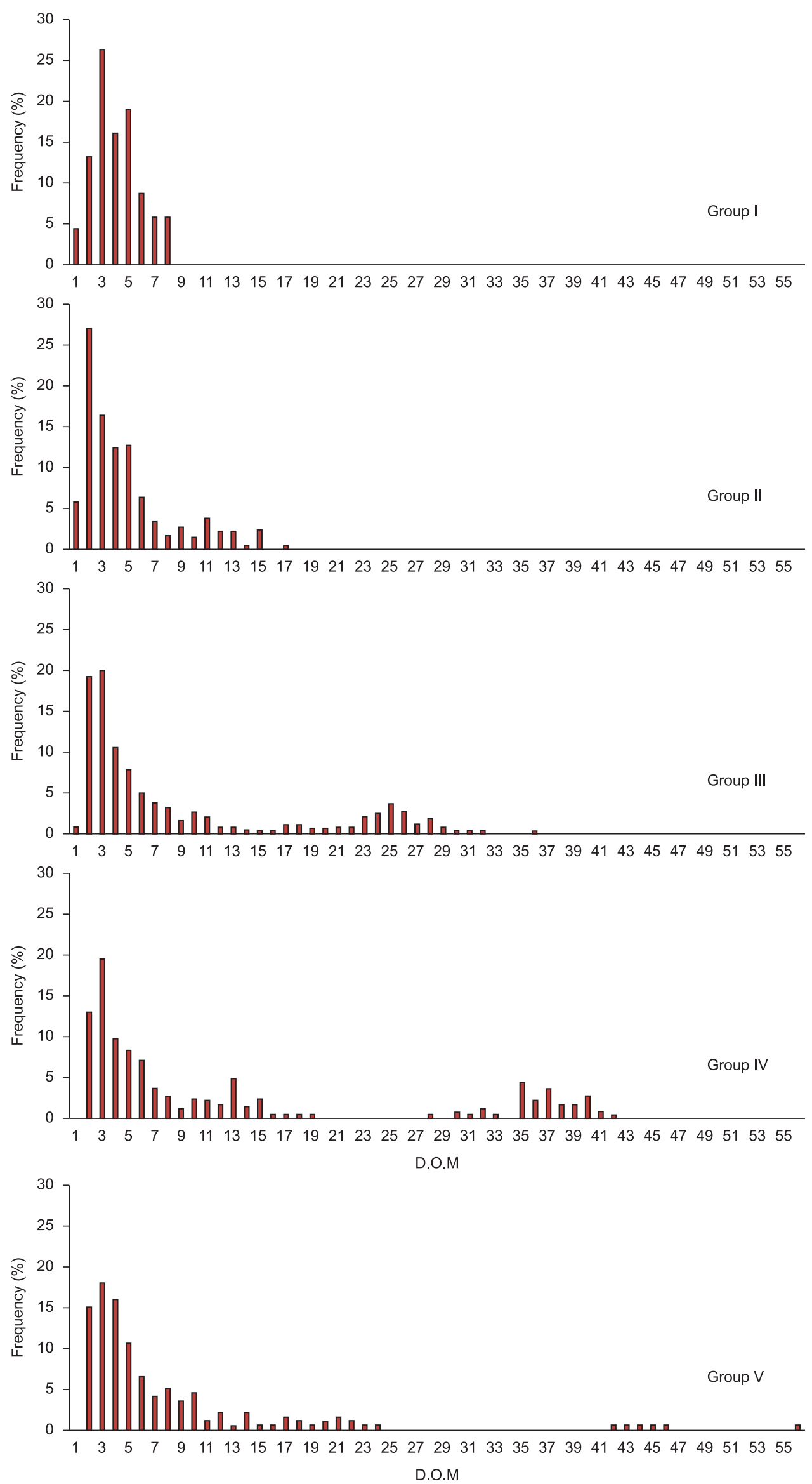

Figure 6. Oocyte size distribution of mature female H. carvalhoi showing five groups (GI-GV) of egg distribution ( 1 d. o. $\mathrm{m} .=61.2 \mu \mathrm{m})$. 
conclusion in this study indicates that $H$. carvalhoi is a total spawning species. Not only for the genus, but the result also differ for $H$. luetkeni. The study done by Mazzoni \& Caramaschi (1997) with $H$. luetkeni mentioned before also indicated a multiple spawning strategy. This indicates that the Loricariidae is a diversified family regarding reproduction.

The gonadossomatic relationship increases among females with immature ovaries to females with mature ovaries and then decreases with the ovaries in the process of depletion, indicating that the mature occytes were released.

The knowledge about reproductive aspects of the species is essential for a better understanding and handling of fish populations, as well as their conservation. Thus, the results of our work are of direct application, which allows us to infer interpretations regarding the reproductive biology of $H$. carvalhoi.

In this context, with a pretty low fecundity, large oocytes, the prolonged and total spawning type presented by $H$. carvalhoi may reflect the ability to better adjust to the environment, since the streams are unstable environments, and larger oocytes give rise to larger larvae that may present greater chance of survival.

\section{Acknowledgements}

We are grateful to CNPq for financial support, Prof. Dr. Francisco Langeani Neto for fish identification, "Núcleo de Educação Ambiental do Ribeirão Grande" for the logistic support and ICMBio for authorising the license for the execution of the fieldwork.

\section{References}

BRAGA, F.M.S. 1999. O grau de preferência alimentar: um método qualitativo e quantitativo para o estudo do conteúdo estomacal de peixes. Acta Sci. Biol. Sci. 21(2):291-295.
BRAGA, F.M.S. 2004. Habitat, distribuição e aspectos adaptativos de peixes da microbacia do ribeirão Grande, Estado de São Paulo, Brasil. Acta Sci. Biol. Sci. 26(1):31-36. http://dx.doi.org/10.4025/actascibiolsci. v26i1.1656

BRAGA, F.M.S. \& ANDRADE, P.M. 2005. Distribuição de peixes na microbacia do ribeirão Grande, Serra da Mantiqueira Oriental, São Paulo, Brasil. Iheringia, Sér. Zool. 95(2):121-126.

ISBRÜCKER, I.J.H. 1980. Classification and catalogue of the mailed Loricariidae (Pisces, Siluriformes). Verslagen en Technische Gegevens, v.22, p.1-181.

MAZZONI, R. \& CARAMASCHI, E.P. 1997. Observations on the reproductive biology of female Hypostomus luetkeni Lacèpéde 1803. Ecol Freshw Fish. 6(1):53-56. http://dx.doi.org/10.1111/j.1600-0633.1997. tb00143.x

MENEZES, M.S., ARANHA, J.M.R. \& CARAMASCHI, E.P. 1998. Ocorrência e aspectos da biologia reprodutiva de Harttia loricariformes (Loricariinae) no trecho inferior do rio Paraíba do Sul (RJ, Brasil). Acta Biol. Par. 27(1-2-3-4):15-26.

NIKOLSKY, G.V. 1963. The ecology of fishes. London: Academic Press.

PETRI, S. \& FÚLFARO, V.J. 1983. Geologia do Brasil (Fanerozóico). Ed. Da Universidade de São Paulo, São Paulo.

REIS, R.E., KULLANDER, S.O. \& FERRARIS JUNIOR, C.J. 2003. Check list of the freshwater fishes of South and Central America. EDIPUCRS, Porto Alegre.

RONDINELI, G.R. 2010. Ictiofauna de duas microbacias - Ribeirão dos Buenos e rio Guaratinguetá - na serra da Mantiqueira oriental. Dissertação de Mestrado, Universidade Estadual Paulista, Rio Claro.

SHINE, R. 1990. Proximate determinants of sexual differences in body size. Am. Nat. 135:278-283. http://dx.doi.org/10.1086/285043

SIEGEL, S. 1975. Estatística não-paramétrica para as ciências do comportamento. McGraw-Hill do Brasil, Rio de Janeiro.

VAZZOLER, A.E.A.M. 1996. Biologia da reprodução de peixes teleósteos: Teoria e Prática. EDUEM, Maringá; São Paulo, SBI. 